\title{
Krzysztof Jędrzejewski
}

\section{Zarządzanie marketingowe jako czynnik rozwoju gminy}

Celem głównym artykułu jest określenie roli zarządzania marketingowego $w$ rozwoju gminy. Autor skoncentrował się na zagadnieniach definicji zarządzania marketingowego, jego znaczeniu w gminach, najważniejszych cechach, jakie go określają oraz wyzwań, które stoją przed władzami gmin w tym zakresie. Co szczególnie ważne, podjęto również próbę oceny stopnia zorientowania marketingowego w zarządzaniu gminą, stosowanych w tym zakresie narzędzi i instrumentów, a także efektów podjętych działań marketingowych.

W opracowaniu przyjęto następującą tezę: władze samorządowe $\mathrm{w}$ gminach muszą uwzględniać nowoczesne rozwiązania w zakresie zarządzania marketingowego, dzięki którym będą mogły sprostać aktualnym wyzwaniom związanym z rozwojem lokalno-regionalnym gminy. Artykuł oparto na literaturze przedmiotu oraz na wynikach własnych badań empirycznych. Metodykę oraz rezultaty badania przedstawiono w dalszej części artykułu.

Zarządzanie marketingowe jest wykorzystywane $\mathrm{w}$ szczególności $\mathrm{w}$ tych gminach, które są zorientowane na rozwój oraz na zaspokajanie potrzeb lokalnej społeczności, inwestorów oraz turystów. Takie działanie to ogólna filozofia i można zaliczyć je do znanych koncepcji zarządzania. Powinno ono być stosowane na każdym poziomie zarządzania jednostką samorządową, tj. na poziomie strategicznym, taktycznym i operacyjnym. Słowo „marketingowe” w tym przypadku wskazuje na koncepcję zarządzania cała gminą.

\section{Znaczenie zarządzania} marketingowego w gminach

Coraz większego znaczenia nabiera zarządzanie marketingowe $\mathrm{w}$ gminach. Współcześnie w swoich działaniach gminy uwzględniają rynki, o które toczy się permanentna konkurencja między różnymi grupami interesów. Odebranie pewnej części siły nabywczej jest w obecnych realiach gospodarczych i społecznych jednym z ważniejszych elementów należących do strategii terytorialnych. Żeby dany region był konkurencyjny, musi on sprostać rywalizacji o względy tzw. „klientów”, czyli swoich mieszkańców, turystów, wczasowiczów, kuracjuszy, inwestorów zewnętrznych itp. Region musi wytwarzać oraz dostarczać im nadrzędnych, satysfakcjonujących różnorodnych wartości i to w dużo bardziej efektywny sposób w porównaniu z konkurencją [Castenow, 1998]. Bez marketingowego podejścia żadna nowoczesna gmina nie może działać efektywnie. Tylko podejmowanie takich kroków pozwoli jej władzom w długim czasie osiągać cele marketingowe. Na tak wielką rolę tego typu zarządzania wpływa szereg elementów, w tym przede wszystkim wciąż rosnąca konku- 
rencja. Przy obecnym zakresie promocyjnym, coraz częściej o rynkowym sukcesie gminy decyduje umiejętność budowania korzystnego wizerunku i umiejętność promowania jej produktów, czy też usług. W tej ważnej dziedzinie najistotniejszy jest jednak czynnik ludzki, czyli cała społeczność gminy, a także jej władze i ich umiejętność zarządzania marketingowego. To właśnie jest kluczem, by osiągnąć sukces rynkowy [Bąk, 2006].

Zarządzanie marketingowe jest tego typu zarządzaniem, które może ułatwić osiągnięcie zamierzonych celów. Należy przez nie rozumieć normatywną naukę obejmującą skuteczne tworzenie i oferowanie wartości, tak aby stymulować pożądane transakcje. Zarządzanie marketingowe regionem, a także kształtowanie polityki regionalnej, jest prowadzone przez samorządy terytorialne, które tworzą w regionach strukturę trójszczeblową (poziom gminy, poziom powiatowy, poziom regionu). Obowiązki te przede wszystkim wynikają z faktu, że samorządy są głównymi reprezentantami interesów mieszkańców oraz odgrywają istotną rolę $\mathrm{w}$ kierowaniu, koordynowaniu oraz nadzorowaniu rozwoju regionu [Sekuła, 2002].

Nadrzędnym celem wszystkich ogniw samorządowych regionu jest dbałość o zapewnienie dalszego rozwoju w skali lokalnej, ale również regionalnej [Kłosiewicz-Górecka, 2001]. Stąd niezwykle ważnym, jak nie najważniejszym zadaniem samorządu terytorialnego jest ciągłe wspieranie, a zwłaszcza kształtowanie konkurencyjności regionu, m.in. poprzez prowadzenie prorozwojowej polityki regionalnej. Zadanie to wynika z przypisanej samorządom istotnej odpowiedzialności wobec całej lokalnej społeczności za podejmowanie $\mathrm{w}$ jej imieniu decyzji i działań, zarówno tych bieżących, jak i tych o wymiarze strategicznym [Zieman-Miszewska, 2005].
Charakterystyczne cechy zarządzania marketingowego w gminach [Florek, 2007]:

- Wdrożenie i realizacja odbywają się przez najwyższe szczeble zarządzania w gminie. Jest to bardzo ważny element, ponieważ bez zrozumienia i akceptacji na najwyższych szczeblach władzy lokalnej, nie jest możliwe wdrożenie zasad zarządzania marketingowego. Nie jest to możliwe nawet w przypadku, gdy gmina dysponuje dobrze przygotowanym zespołem zajmującym się marketingiem. Jeżeli orientacja rynkowa ogranicza się tylko do działu marketingu gminy, to zdecydowanie osłabia to jej całą rynkową pozycję. Turbulentne otoczenie wymusza na gminie rozszerzenie ogólnej orientacji marketingowej na jej cele, w tym również rozwojowe.

- Praktyczne urzeczywistnienie filozofii marketingowej w gminie. Szczególną rolę odgrywają tu władze gminy, które powinny umiejętnie oddziaływać na całą społeczność. Powinny również w swoich działaniach stosować tę filozofię bez względu na miejsce gminy $\mathrm{w}$ regionie.

- Koordynacja głównych funkcji gminy. Nadrzędną cechą powinno być zorganizowane i uporządkowane współdziałanie władz gminy w oparciu o marketing. Ma on naturalną zdolność do koordynacji wszystkich funkcji jednostki. Takiej zdolności nie ma żadna inna funkcja gminy. Wynika to z istnienia tzw. zamkniętego cyklu, który obejmuje gminę wraz z jej otoczeniem i ma on charakter ciągły. Marketing można tu również porównywać do układu nerwowego gminy, w którym funkcję mózgu pełnią władze gminne.

- Integracja działalności gminy wokół strategicznych celów. Cele strategiczne są rezultatem dokładnego planowania strategicznego, a to wymaga zaangażowania specjalistów z różnych dziedzin, 
w tym również marketingu. Dla realizacji określonych celów ważne jest połączenie wszystkich współpracujących elementów w stałe bądź okresowe zespoły.

- Ciągłość strategicznego planowania marketingowego. Ciągłość planowania oznacza, że głównym warunkiem rozpoczęcia prac w następnym etapie planowania, nie jest ostateczne zakończenie prac w poprzednim etapie. Proces planowania w szczególności wymaga reagowania na bieżące zmiany oraz wykorzystywanie tych informacji do nanoszenia korekt i dokonywania ewentualnych modyfikacji. Plan strategiczny jest głównym narzędziem do realizacji koncepcji zarządzania marketingowego.

Zarządzanie marketingowe, w powiązaniu z budżetem danej gminy oraz planami strategicznymi, staje się ważnym instrumentem wszelkich działań władz gminy. Jako dokument kierunkowy, zarządzanie marketingowe pełni funkcję drogowskazu w realizacji przedsięwzięć lokalnych. Wraz ze zmieniającymi się wewnętrznymi i zewnętrznymi warunkami należy je aktualizować, a także poszerzać i to już na każdym poziomie planowania.

Systematyczne i długookresowe zarządzanie marketingowe prowadzone na rzecz rozwoju gminy, nadal nie należy do powszechnej zasady działania władz gminnych w całej Polsce. Podstawowa trudność budowania odpowiedniego klimatu dla tego typu prowadzonych działań wynika z mentalności oraz nawyków, jak również braku wiedzy wśród członków władz, a także pracowników samorządowych. Pojęcie zarządzania marketingowego jest kojarzone przede wszystkim ze sferą gospodarki (przedsiębiorstwem). W wielu przypadkach, najważniejsze instrumenty zarządzania marketingowego traktowane są wręcz za konieczność wynikającą z mody przejściowej. Uznawane są także za formalny wymóg, niewnoszący istotnych zmian do prowadzonej praktyki funkcjonowania gminy (dla przykładu: przy ubieganiu się o wszelkie środki pomocowe Unii Europejskiej). Ponadto, do długookresowego jak też kompleksowego zarządzania marketingowego gminą zniechęca wybór radnych oraz wójtów, burmistrzów czy prezydentów głównie na okres czteroletniej kadencji, bo sprzyja to myśleniu w perspektywie jedynie krótkookresowej. Zasadniczym jednak problemem nadal jest brak dostatecznej wiedzy u władz gmin i pracowników samorządowych, dotyczącej korzyści płynących głównie dla społeczności lokalnej, które wynikają z praktycznego stosowania marketingowego zarządzania gminą. To ma wpływ na to, że w gminach rzadko stosuje się podejście marketingowe, które jest podstawą kompleksowego kształtowania ich rozwoju. Dużo częściej władze gmin wykorzystują jedynie poszczególne elementy tej koncepcji.

Jako przykład można podać tu strategie rozwoju gminy całkowicie bez programów i różnych planów realizacyjnych, opracowywanie wieloletniego inwestycyjnego planu bez jednoczesnego sporządzania wieloletniego finansowego planu, brak programów promocji gminy bądź też ich złe przygotowanie (nie mają one zdefiniowanego odbiorcy, stąd ich wszelkie ustalenia nie wiadomo dokładnie do kogo są adresowane) [Ziółkowski, 2015].

Każda polska gmina ma dziś w zasadzie mniej lub bardziej dopracowaną strategię rozwoju, w oparciu o którą stara się rozwiązać bieżące oraz perspektywiczne problemy. Prowadzi politykę rozwojową, marketing gminny, promocję gminy czy też konstruuje budżet i realizuje różne inwestycje własne oraz zabiega w dużej części o inwestorów [Parysek, 2010]. Ważną kwestią jest, coraz wyraźniej dostrzeganą przez wielu specjalistów, konkurencja gmin. Pojmowana jest ona jako wyraz ich podejścia rynkowego, w 
którym dokładnie chodzi o zwiększenie atrakcyjności gmin, a w istocie o zdobycie przewagi konkurencyjnej nad innymi gminami [Wojciechowski, 2003]. Zarządzanie marketingowe $\mathrm{w}$ gminie nie może więc pozostawać całkiem obojętne ze strony innych gmin. Musi mobilizować zasoby lokalne do tworzenia różnych warunków sprzyjających aktywizacji gospodarczej, jak również rozwojowi gminy [Kowalczyk, 2004].

\section{Nowoczesne ujęcie}

\section{zarządzania marketingowego}

W nowoczesnym ujęciu, cały proces zarządzania marketingowego jest złożony z pięciu etapów: analizy możliwości marketingowych, badania i selekcjonowania rynków docelowych, projektowania strategii marketingowych - sporządzania planów marketingowych, jak również organizowania, wdrażania i kontrolowania prowadzonej działalności marketingowej [Strużycki, 2002].

Zarządzanie marketingowe gminą to proces ciągłej analizy otoczenia, a także planowania decyzji, ich wdrażania oraz kontroli ich realizacji. Jest to działanie ciągłe, którego najważniejszym celem jest doskonalenie prowadzonej działalności marketingowej i stałe jej dostosowywanie do zmieniającego się otoczenia. To dziedzina wyspecjalizowanego zarządzania, które jest realizowane na poziomie operacyjnym obecnej strategii rozwoju, z uwzględnieniem wszystkich typowych funkcji zarządzania, takich jak np.: planowanie, organizowanie czy też motywowanie i kontrolowanie [Urban, 2003].

Nowoczesne zarządzanie marketingowe w głównej mierze nastawione jest na działania długookresowe, które zmierzają do [Ziółkowski, 2015]:

- kreowania potrzeb inwestorów/turystów/mieszkańców zgodnie z własnymi interesami danej gminy,

- zdefiniowania potrzeb docelowych grup nabywców/klientów oraz dostar- czenia im potrzebnego produktu lub usługi w sposób bardziej efektywny oraz wydajny niż konkurenci - orientacja skierowana na klientów oznacza, że z racji pragnienia pozyskania i utrzymania klientów przy sobie, należy dokonywać identyfikacji i prognozowania ich najważniejszych potrzeb,

- zwiększania pozycji konkurencyjnej danej gminy w jej otoczeniu,

- kształtowania jak najbardziej pozytywnego wizerunku gminy.

We współczesnej metodyce zarządzania marketingowego w gminie zaleca się stosowanie koncepcji dotyczącej zarządzania strategicznego, które winno być ściśle powiązane $\mathrm{z}$ prowadzonymi działaniami marketingowymi. W myśl owej koncepcji, zarządzanie marketingowe jest dobrze przemyślanym, perspektywicznie zaplanowanym, a także skutecznie zorganizowanym i efektywnie wykonywanym oraz stale kontrolowanym procesem wdrażania i formułowania strategii rozwoju organizacji. Koncepcja ta skupia uwagę zarządzających gminą głównie na jak najlepszym wykorzystaniu posiadanych walorów i zasobów w perspektywie długookresowej. Chodzi tu o rozwój swojego (endogenicznego) potencjału, który w następstwie określa poziom atrakcyjności lokalizacyjnej oraz konkurencyjności danej gminy w otoczeniu. Z kolei prowadzone działania marketingowe wspomagają skuteczną, jak również efektywną realizację ustaleń strategicznych. Najważniejszym zadaniem marketingu jest rozpoznanie wszelkich potrzeb, wymagań i oczekiwań ze strony potencjalnych klientów, a następnie posiadanie usług i produktów, które będą dla owych nabywców (inwestorów, turystów) źródłem większych korzyści (użyteczności) niż te oferowane przez konkurencję. Ważne miejsce powinny zajmować także problemy aktywnego budowania pozytywnego wizerunku gminy, jak również zwiększa- 
nia jej pozycji i atrakcyjności w bliskim otoczeniu.

W toku realizacji zarządzania marketingowego dokonuje się wyboru takich rynków, na których dana gmina będzie konkurować z innymi, określa się również dokładnie sposoby osiągania trwałej przewagi konkurencyjnej. Coraz częściej, poza planami operacyjnymi krótkoterminowymi dotyczącymi działań promocyjnych, gminy tworzą również długookresowe strategie promocji. Takie działania wywołują relacje między nadawcą a adresatem. Można zatem mówić w tym przypadku o powstawaniu kapitału relacyjnego właśnie w oparciu o różne działania promocyjne. Ponadto, zbudowanie kapitału relacyjnego może z kolei gminom przynosić profity przez kilka lat [Chrząścik, 2012].

Dobrze realizowane zarządzanie marketingowe $\mathrm{w}$ gminie powinno odznaczać się dużą intensywnością, a także różnorodnością i skutecznością. Bardzo istotna jest kontynuacja i nasilenie wszelkich działań promocyjno-reklamowych. Działania owe muszą być prowadzone przez indywidualne podmioty lokalne $\mathrm{w}$ skoordynowany sposób, nie dopuszczając do konkurencji wewnętrznej. $Z$ uwagi na siłę psychologicznego oddziaływania na nabywców, reklama jest najistotniejszym narzędziem promocji gmin. Wszystkie prowadzone działania reklamowe są kosztowne lecz konieczne i należy traktować je jako niezbędne inwestycje. Dodatkowo gmina, która stosuje zarządzanie marketingowe, posługuje się głównie informacją. System informacyjny gminy powinien być uporządkowany oraz przejrzysty i stwarzać możliwości do przesyłania sugestywnej informacji o aktualnej ofercie gminy. Informacja ta winna być szeroko dostępna zarówno w regionie jak i w całym kraju, a także za granicą. Ostatnio dużego znaczenia nabrało rozpowszechnianie informacji za pośrednictwem Internetu. We współczesnym świecie konkurencja staje się wręcz wszechobecna i przybiera charakter totalny. To właśnie w ślad za nią wszędzie podąża marketing. Stąd również i gminy, a zwłaszcza usługi komunalne, muszą w swoich działaniach stosować marketing. Pod względem ekonomicznym, skuteczne i korzystne wdrażanie strategii rozwojowych gmin staje się jednak niemożliwe bez pomocy ze strony marketingu [Urban, 2003].

W Polsce coraz bardziej kształtuje się rynek różnych jednostek samorządu gminnego, który staje się rynkiem o rosnącym znaczeniu konkurencyjnym. Jest to konkurencja, w której w szczególności chodzi o nowych mieszkańców, a także inwestorów zewnętrznych i potrzebne środki finansowe - czyli konkurencja o wymierne korzyści dla całej społeczności gminnej. Od tego w dużej mierze zależy rozwój gospodarczy, który jest głównym wyznacznikiem realnych możliwości zaspokajania wszystkich zbiorowych potrzeb mieszkańców. Rywalizowanie różnych gmin o te korzyści, to wyraz normalnego podejścia rynkowego.

\section{Wyzwania ekonomiczne dla władz samorządowych}

$\mathrm{Na}$ władzach danej gminy spoczywa obowiązek aktywnego kierowania procesami rozwoju lokalnego poprzez wszelkie działania regulacyjne, inicjujące, organizujące oraz stymulujące. Wymaga to aktywności, kreatywności, innowacyjności i determinacji w działaniach władz gminy. Wymaga również znajomości uwarunkowań i ogólnych mechanizmów jej rozwoju, wiedzy oraz umiejętności umożliwiających stosowanie nowoczesnych metod zarządzania i podejmowanie racjonalnych prorozwojowych decyzji oraz zastosowanie właściwych instrumentów dotyczących oddziaływania na skalę, jak też tempo tegoż rozwoju [Ziółkowski, 2015].

W wyniku dyskusji o zarządzaniu marketingowym, a także głównie w oparciu o wnioski z diagnozy gospodarczo- 
-ekonomicznej, można sformułować kilka wyzwań stojących przed wspólnotą samorządową. W tej kwestii na pierwszy plan wyłaniają się potrzeby dotyczące dynamizowania rozwoju gospodarczego, a także wykorzystania atutów danej gminy. Bardzo ważnym elementem tego wyzwania jest poprawa w gminie wewnętrznej dostępności komunikacyjnej, która może być barierą rozwojową.

Następne wyzwanie w tym zakresie, to wzmacnianie pozycji gospodarczej gminy. Może to $\mathrm{w}$ przyszłości zagwarantować efektywne rozwiązywanie problemów społecznych oraz zapewnić stabilizację dla finansów publicznych gminy. Wzmacnianie pozycji gospodarczej gminy uwarunkowane jest inwestycjami gminnymi i prywatnymi (czyli zagospodarowanie istniejących terenów inwestycyjnych, a także rewitalizacja przestrzeni poprzemysłowych), jak również zewnętrznymi (m.in. poprawa dotychczasowej przepustowości dróg krajowych i wojewódzkich na terenie gminy, a także budowa obwodnic oraz systemu kolei aglomeracyjnej itp.). Ważnym działaniem w ramach niniejszego wyzwania może być również rewitalizacja obszarów poprzemysłowych oraz wolnych niezagospodarowanych terenów. Przekształcanie tych przestrzeni, ich odnowa techniczna oraz nadanie całkiem nowych funkcji (gospodarczych, społecznych, a także rekreacyjnych) będzie tworzeniem nowych tzw. „ognisk” wzrostu, czyli różnych miejsc atrakcyjnych dla zamieszkania bądź też podjęcia działalności gospodarczej.

Ewolucja zarządzania publicznego postawiła głównie przed władzami lokalnymi całkiem nowe wyzwania, które zmierzają do stworzenia właśnie takiego systemu zarządzania gminą, który odpowiadałby na potrzeby społeczności lokalnej oraz stwarzał możliwości jej dynamicznego rozwoju. Sytuacja ta wymusiła strategiczne podejście do zarządzania gminą, rozumiane jako ukierunkowa- ny proces na przyszłość, uwzględniający wszelkie zmiany w otoczeniu gminy, dotyczący planowania i formułowania celów ogólnego rozwoju jednostki, doboru narzędzi oraz działań realizacyjnych, wdrażania przyjętych wcześniej założeń, a także całkowitej kontroli ich wykonania [Kuźniar, 2013].

Głównym wyzwaniem przy tworzeniu planów zarządzania marketingowego jest poszukiwanie takiego pozycjonowania, które nie tworzy sztucznych korzyści na pożądanych cechach, a wręcz odnajduje unikatowy emocjonalny tzw. „kod”, który najdokładniej charakteryzuje odpowiednie miejsce. W takim komunikacie winny znaleźć się najważniejsze cechy gminy tak konstruowane są wszystkie najlepsze „oferty wartości”. Polskie gminy zaczynają szukać inspiracji właśnie w tych obszarach. Sięgają bardzo często do źródeł, postaci historycznych, atrakcji turystycznych, potencjału wiedzy i nauki czy też flagowych wydarzeń. Liczba skojarzeń, z których korzystać może właściciel marki miejsca, jest wręcz nieograniczona. Tym większej wyobraźni może wymagać znalezienie wyróżnika, który pozwala na rozciągnięcie marki gminy na wszystkie jej aktywności [Mikołajczyk, 2010/2011].

Zarządzanie marketingowe jest problemem interdyscyplinarnym. W owym kontekście, istotę tego zarządzania ujawnia zestawienie elementów danej organizacji terytorialnej (środowisko, kapitał ludzki, organizacje społeczno-gospodarcze) razem z takimi wyznacznikami, jak wszelkie procesy rozwojowe wynikające z ogólnej natury zmian terytorium, postawy zarządcze wobec cywilizacyjnych wyzwań, podsystemy branżowe, które są związane z zadaniami i terenami aktywności gminy oraz ich dyslokacją w ogólnej przestrzeni, wreszcie wszystkie etapy procesu zarządzania marketingowego: planowanie, organizowanie, wdrażanie planów oraz programów, kontrola, monitoring, a także ewaluacja. Uwzględniając nowe ro- 
zumienie prowadzonej polityki regionalnej, wskazać warto najważniejsze elementy, które warunkują sprawniejsze, czyli skuteczniejsze i bardziej ekonomiczne działania władz gminy [Noworól, 2007].

W pierwszej kolejności zauważyć trzeba wzrost złożoności, jak również różnorodności struktur zarządzania marketingowego. Następować to może poprzez wewnętrzną dezagregację organizacyjną administracji publicznej, dezagregację struktur i wszystkich systemów zarządzania majątkiem, jak również finansami (od gospodarki budżetowej, poprzez urynkowienie usług, po prywatyzację). Ponadto, dla zarządzania obszarami funkcjonalnymi, będącym zbiorem gmin, właściwym rozwiązaniem powinny być konkretne związki i stowarzyszenia. Założyć trzeba, że dla zarządzania różnymi obszarami funkcjonalnymi, działającymi głównie na terenach, które nie pokrywają się z granicami administracyjnymi podmiotów zarządzających, będą trójsektorowe, czyli tzw. hybrydowe partnerstwa publiczno-prywatno-społeczne. Są one oparte na współpracy administracji gminy z partnerami pozarządowymi, a także gospodarczymi. Zarządzanie marketingowe powinno opierać się na wzroście zdolności autoregulacji podsystemu zarządzania. Głównym warunkiem tego jest decentralizacja oraz wykorzystanie zasad pomocniczości. Autoregulacji w tym przypadku sprzyja tworzenie mechanizmów uczestnictwa danej gminy w podejmowaniu decyzji publicznych, rozumiane jako nowa płaszczyzna dialogu pomiędzy administracją i władzą a sektorem biznesowym, społecznym oraz mieszkańcami, między innymi poprzez transparentność i jawność decyzji zarządczych, techniki społecznej partycypacji w zarządzaniu, opartych na deliberacyjnych procedurach i wykorzystywaniu narzędzi e-administracji. Ponadto, myślenie portfelowe o wszelkich projektach partnerstw hybry- dowych też może sprzyjać samoregulacji i oznacza, że owe projekty będą w dużo mniejszym stopniu związane $\mathrm{z}$ prowadzonym marketingiem politycznym, a w stopniu większym, z uzgodnionymi celami zarządzania marketingowego partnerstw [Noworól, 2013].

Nowe zarządzanie marketingowe kładzie w dużym stopniu nacisk na zwiększenie innowacyjności. Wszystko to dotyczy bazowania na endogenicznym potencjale rozwojowym danej gminy oraz na mechanizmach wsparcia egzogenicznego. Fundamentem innowacyjności pozostanie wciąż zarządzanie marketingowe, obejmujące selekcję priorytetów i zintegrowane podejście do równoważenia rozwoju gminy. W nowym kontekście spojrzeć należy na ewaluację interwencji, która stanie się czynnikiem procesu uczenia się. Następnym istotnym elementem zarządzania rozwojem jest tzw. zintensyfikowanie powiązań z otoczeniem gminy, poprzez zwiększenie jakości, a także liczby kanałów wymiany produktów i usług. Przez kanał wymiany należy rozumieć sieci przepływów: transportowe, kapitałowo-finansowe, a także informacyjne. Ponadto, w społeczeństwie sieciowym władze gminy uzyskują większy wpływ na animowanie współpracy między gminami [Domański, 2006].

\section{Metodyka badania}

$Z$ punktu widzenia tematyki badania, istotne jest zwrócenie uwagi na praktyczny aspekt analizowanych zagadnień. Celem badania była ocena działań marketingowych podejmowanych przez władze samorządowe gmin.

Badania przeprowadzono na terenie województwa łódzkiego $\mathrm{w}$ okresie maj - sierpień 2016 roku. Badaniami objęto wszystkie gminy tego województwa. Terytorium województwa łódzkiego przyjęto ze względów pragmatycznych. Zastosowano metodę ankietową, a instrumentem pomiarowym był kwestionariusz. 
Tablica 1 Stosowanie podejścia marketingowego w zarządzaniu przez władze gmin

\begin{tabular}{lrrrrr}
\hline $\begin{array}{l}\text { Czy w zarządzaniu strategicznym } \\
\text { władze samorządowe gminy } \\
\text { stosują podejście marketingowe? }\end{array}$ & miejskie & $\begin{array}{c}\text { Gminy (liczba) } \\
\text { miejsko- } \\
\text {-wiejskie }\end{array}$ & wiejskie & liczba & Ogółem \\
tak, w całej rozciągłości & 1 & 6 & 9 & 16 & $10,7 \%$ \\
tak, w pewnych obszarach & 12 & 18 & 60 & 90 & $60,4 \%$ \\
tak, incydentalnie & 2 & 1 & 29 & 32 & $21,5 \%$ \\
\hline raczej nie & 0 & 0 & 11 & 11 & $7,4 \%$ \\
\hline ogółem & 15 & 25 & 109 & 149 & $100 \%$ \\
\hline
\end{tabular}

Źródło: opracowanie własne na podstawie wyników badania.

Przygotowany kwestionariusz ankietowy zawierał 11 pytań głównych związanych z zarządzaniem marketingowym i został skierowany do kadry zarządzającej 176 gmin, w tym: 17 gmin miejskich, 26 gmin miejsko-wiejskich i 133 gmin wiejskich. Ostatecznie w badaniu udział wzięto 155 gmin, w tym: 15 gmin miejskich, 25 gmin miejsko-wiejskich i 115 gmin wiejskich. Na pytania zawarte w kwestionariuszu odpowiedzi udzielili przedstawiciele kadry zarządzającej gmin, np.: wójt, burmistrz, prezydent, a także pracownicy odpowiedzialni za promocję. Rezultaty badania zaprezentowano łącznie dla trzech typów gmin: miejskich, miejsko-wiejskich i wiejskich.

W toku badań postawiono hipotezę o następującej treści: Gminy orientują się na klienta wewnętrznego i zewnętrznego wykorzystując w swojej działalności różne narzędzia marketingu.

\section{Wyniki badania}

Zarządzanie marketingowe powinno być podstawowym elementem w zarządzaniu strategicznym i operacyjnym $\mathrm{w}$ gminach. Elementy marketingu władze samorządowe powinny wykorzystywać we wszystkich sferach swojej aktywności gospodarczej i społecznej. W przypadku gmin miejskich, miejsko-wiejskich i wiejskich, podejście marketingowe $\mathrm{w}$ zdecydowanej większości gmin stosowane jest jedynie w pewnych obszarach, a w gminach wiejskich w bardzo dużej części tylko incydentalnie lub też nie jest stoso- wane. W całej zbiorowości gmin, prawie 60 proc. odpowiedzi wskazało, że władze samorządowe stosują podejście marketingowe, 21 proc. że incydentalnie, a tylko 10 proc. respondentów udzieliło odpowiedzi, że stosuje we wszystkich swoich działaniach - tablica 1 .

Cel działań marketingowych jest jednym z podstawowych elementów, które mogą generować korzyści dla gminy. Wybór celu jest bardzo ważny, gdyż określa on kierunek działania władz samorządowych. W przypadku gmin, za cel działań marketingowych realizowanych przez władze gminy można uznać ogólnie rozumiany rozwój. Uwzględniając szczegółowe dane należy wskazać, że według przedstawicieli gmin, celem tych działań jest rozwój ekonomiczno-przemysłowy oraz kulturalny i oświatowy. Równie istotne są: poprawa warunków życia mieszkańców, postrzeganie gminy, budowanie pozytywnego wizerunku, na co zwróciło uwagę ponad 60 proc. badanych. Można zatem stwierdzić, że cele te dotyczą zachowania harmonii oraz odpowiedniego poziomu życia mieszkańców, mogą być również formą zachęty do zamieszkania w gminie - rysunek 1 .

Gminy mają na swoim terenie określone zasoby naturalne, przemysłowe oraz różne atrakcje turystyczne. Ważne jest aby władze samorządowe określiły, co jest atutem gminy i co pozwoli określić przedmiot działań marketingowych, który będzie podejmowany $\mathrm{w}$ promocji gminy. 
Rysunek 1 Cel działań marketingowych realizowanych przez władze samorządowe gmin (struktura w \% ogółem odpowiedzi)

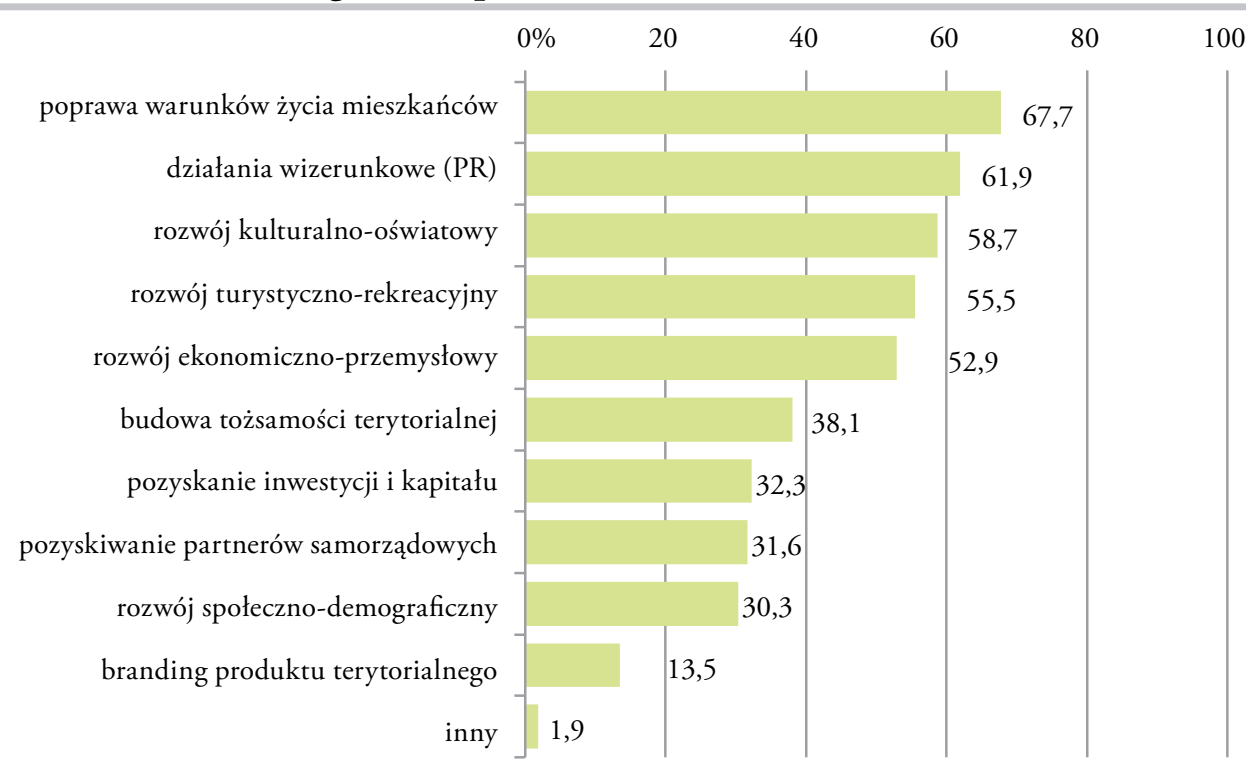

Źródło: opracowanie własne na podstawie wyników badania.

Obecnie przedmiotem działań marketingowych realizowanych przez władze gmin są głównie zasoby gminy oraz przedsięwzięcia kulturalne i sportowe (ponad 70 proc.), nieruchomości i tereny inwestycyjne oraz atrakcje turystyczne (ponad 40 proc.) - rysunek 2 .

Wyzwania, przed jakimi stają władze gmin, są powiązane z tym, w jaki sposób wykorzystać atuty gminy w celu kreowania pozytywnego wizerunku dla klientów zewnętrznych (inwestorów, turystów) jak i wobec mieszkańców. Aby osiągnąć efekt rozwoju gminy, jej pozytywnego wizerunku, władze gmin powinny wykorzystywać narzędzia jakie daje im marketing. Szczególnie ważnym elementem jest promocja, dzięki której można pokazać nie tylko atuty gminy, ale również te jej elementy, które mogą być zachętą dla turystów czy inwestorów. Wykorzystanie narzędzi marketingu terytorialnego pozwala na osiągnięcie przez gminy korzyści nie tylko o charakterze finansowym, ale też wizerunkowym. W przypadku gmin, podstawowym instrumentem jest reklama, którac stosuje ponad 80 proc. gmin oraz public relations (ponad 60 proc). Zdecydowanie w mniejszym stopniu gminy w swojej działalności marketingowej wykorzystują targi czy sponsoring - rysunek 3.

\section{Rysunek 2 Przedmiot działań marketingowych podejmowanych przez władze} gmin (struktura w \% ogółem odpowiedzi)

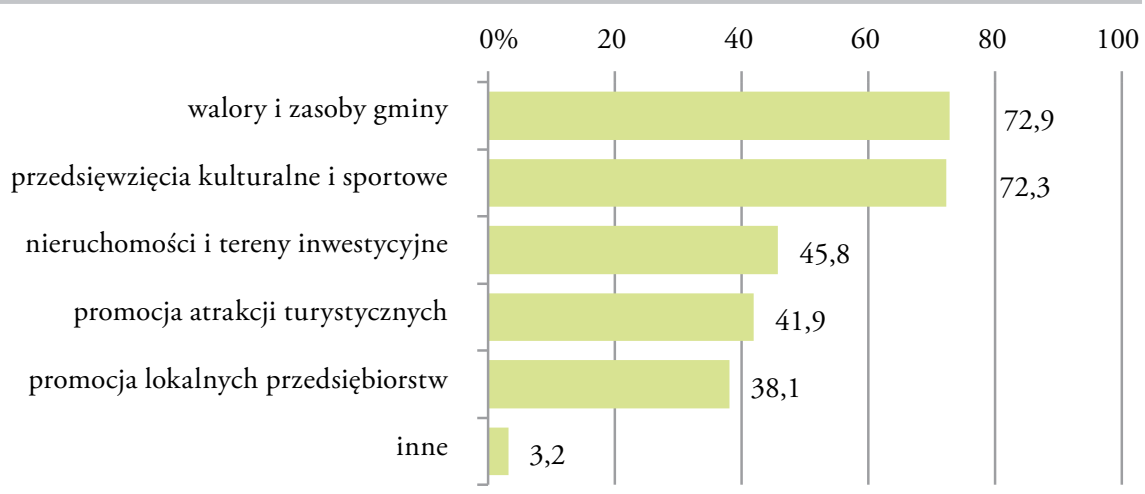


Rysunek 3 Instrumenty promocji wykorzystywane przez władze gmin (struktura w \% ogółem odpowiedzi)

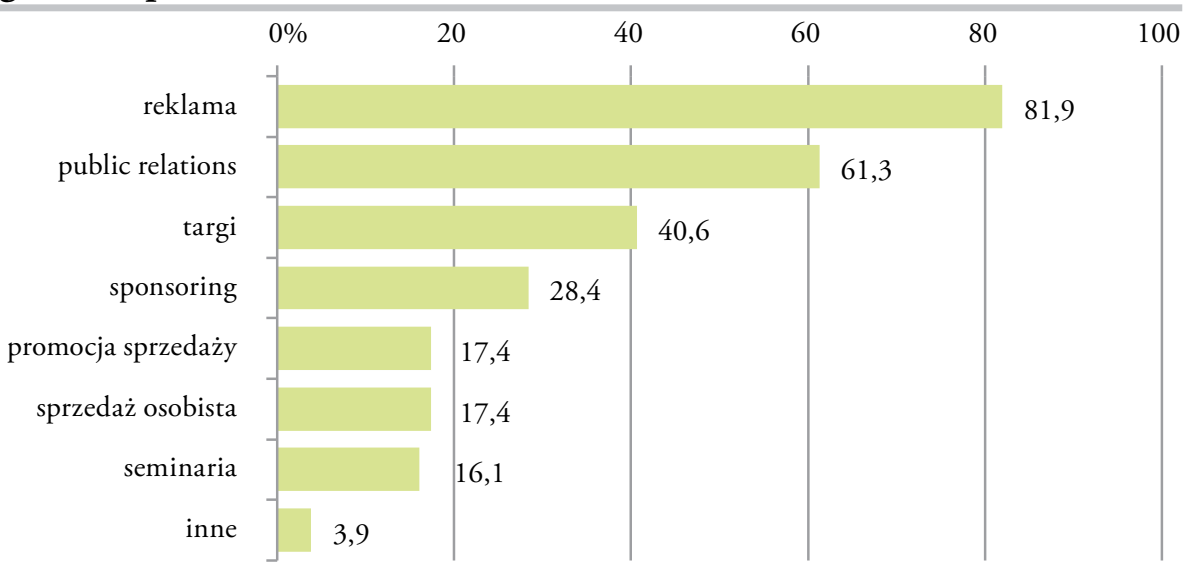

Źródło: opracowanie własne na podstawie wyników badania.

Rozwój gmin, zadowolenie mieszkańców i przekonanie o atrakcyjności własnej gminy, poziom życia, liczba imprez sportowych czy wydarzeń kulturalnych, podlegają ocenie przez mieszkańców czy też turystów. Skuteczność stosowanych narzędzi marketingu w działaniach władz samorządowych przekłada się na postrzeganie gminy przez klientów wewnętrznych, zewnętrznych oraz władze wojewódzkie. Miernikiem oceny skuteczności działań promocyjnych jest rozwój gospodarczy, wzrost poziomu życia mieszkańców czy też zainteresowanie turystów. Dlatego tak bardzo ważne jest, aby instrumenty promocji wykorzystywane przez władze gmin były skuteczne. Reklama i public relations zostały ocenione najwyżej przez władze gmin. Zdaniem respondentów, promocja sprzedaży i sprzedaż osobista jest mniej skuteczna, a najsłabiej skuteczne są seminaria (tablica 2).

W obecnych czasach, kiedy szybkość przekazu informacji i jej dostępność nabierają zdecydowanego znaczenia w dotarciu do odbiorców, władze samorządowe zmuszone są do stosowania nowoczesnych kanałów przekazu. Zdecydowanie najważniejszym kanałem komunikowania się władz samorządowych $\mathrm{z}$ otoczeniem jest Internet. Wszystkie gminy wykorzystują

\section{Tablica 2 Skuteczność instrumentów promocji}

\begin{tabular}{|c|c|c|c|c|c|c|}
\hline $\begin{array}{l}\text { Instrumenty } \\
\text { promocji }\end{array}$ & $\begin{array}{l}\text { bardzo } \\
\text { wysoko }\end{array}$ & wysoko & przeciętnie & nisko & $\begin{array}{c}\text { bardzo } \\
\text { nisko }\end{array}$ & $\begin{array}{l}\text { średnia } \\
(1-5)\end{array}$ \\
\hline $\begin{array}{l}\text { reklama } \\
(\mathrm{n}=127)\end{array}$ & $14,2 \%$ & $48,8 \%$ & $34,6 \%$ & $2,4 \%$ & $0,0 \%$ & 3,75 \\
\hline $\begin{array}{l}\text { public relations } \\
(\mathrm{n}=95)\end{array}$ & $13,7 \%$ & $62,1 \%$ & $24,2 \%$ & $0,0 \%$ & $0,0 \%$ & 3,89 \\
\hline $\begin{array}{l}\text { promocja } \\
\text { sprzedaży } \\
(n=27)\end{array}$ & $3,7 \%$ & $48,1 \%$ & $44,4 \%$ & $3,7 \%$ & $0,0 \%$ & 3,52 \\
\hline $\begin{array}{l}\text { sprzedaż } \\
\text { osobista }(n=27)\end{array}$ & $11,1 \%$ & $40,7 \%$ & $37,0 \%$ & $11,1 \%$ & $0,0 \%$ & 3,52 \\
\hline $\begin{array}{l}\text { sponsoring } \\
(\mathrm{n}=44)\end{array}$ & $11,4 \%$ & $27,3 \%$ & $54,5 \%$ & $4,5 \%$ & $2,3 \%$ & 3,41 \\
\hline $\operatorname{targi}(\mathrm{n}=63)$ & $17,5 \%$ & $36,5 \%$ & $31,7 \%$ & $7,9 \%$ & $6,3 \%$ & 3,51 \\
\hline $\begin{array}{l}\text { seminaria } \\
(n=25)\end{array}$ & $4,0 \%$ & $40,0 \%$ & $32,0 \%$ & $20,0 \%$ & $4,0 \%$ & 3,20 \\
\hline
\end{tabular}

* średnia obliczana jest dla kodów/rang: bardzo wysoko: 5, wysoko: 4, przeciętnie: 3, nisko: 2, bardzo nisko: 1, gdzie im wyższa wartość średniej tym wyższa ocena skuteczności

Źródło: opracowanie własne na podstawie wyników badania. 
Rysunek 4 Kanały przekazu promocyjno-wizerunkowego wykorzystywane przez gminy (struktura w \% ogółem odpowiedzi)

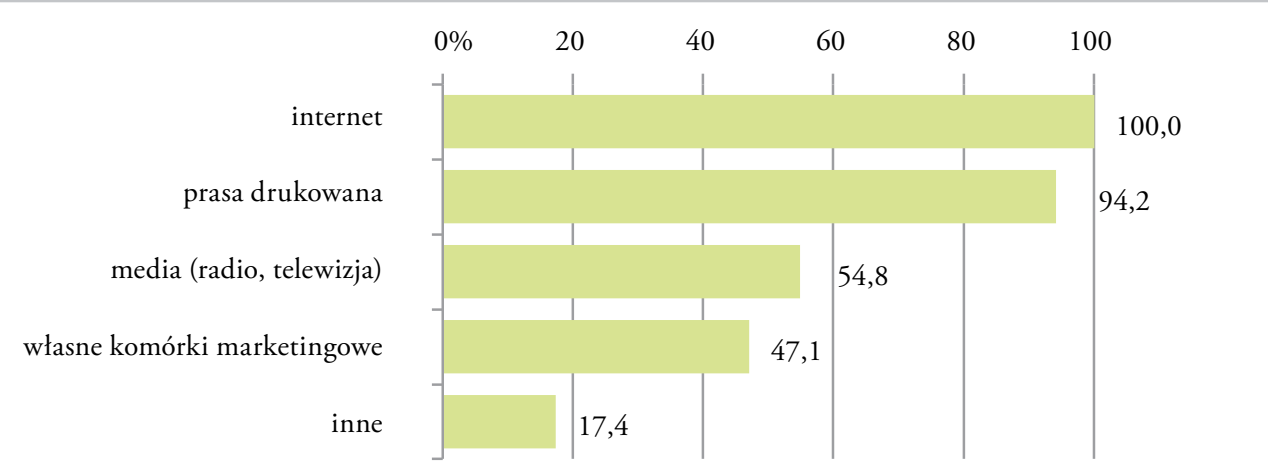

Źródło: opracowanie własne na podstawie wyników badania.

ten sposób komunikacji i promocji. Tradycyjne kanały przekazu i działań marketingowych, jak prasa drukowana czy radio, są wykorzystywane, ale w mniejszym zakresie - rysunek 4.

Aby gmina była rozpoznawalna i były realizowane cele rozwojowe, podejmowane i realizowane działania marketingowe muszą być zaplanowane, spójne i systematyczne. Tylko 31 proc. gmin planuje politykę wizerunkową, 53 proc. raczej uważa, że planuje, a prawie 15 proc. nie planuje. Podobne wyniki respondenci wskazali w przypadku systematyczności i spójności działań marketingowych w gminach. Prowadzenie zaplanowanych i systematycznych działań marketingowych przekłada się na ocenę aktywności. Większość gmin w województwie łódzkim ocenia, że aktywność działań marketingowych jest na dobrym lub bardzo dobrym poziomie, a tylko (38 proc.) ocenia średnio aktywność władz samorządowych w tym zakresie - rysunek 5.

Wyniki badań pozwoliły na sformułowanie następujących wniosków:

- nie wszystkie gminy województwa łódzkiego w swoich działaniach stosują elementy marketingu terytorialnego;

- władze gmin stosują nowoczesne techniki kontaktu z otoczeniem;

- większość gmin województwa łódzkiego w swoich działaniach marketingowych uwzględnia określone cele największy nacisk władze gmin kładą na te zmierzające do rozwoju ekonomicznego i turystyczno-rekreacyjnego obszaru, poprawy życia mieszkańców i wizerunku danego terytorium;

- w zdecydowanej większości gmin celem działań marketingowych są walory

Rysunek 5 Ocena aktywności działań marketingowych w gminach (w \% ogółem odpowiedzi)

60

45,2

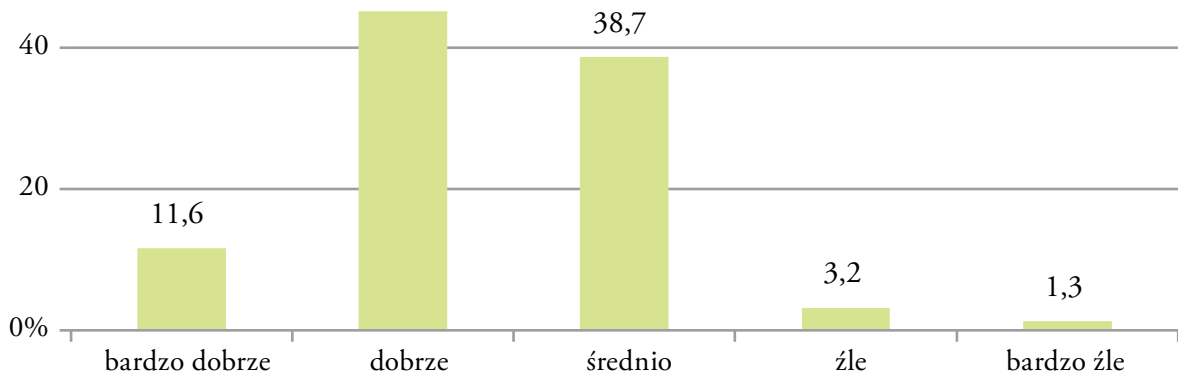

Źródło: opracowanie własne na podstawie wyników badania. 
i zasoby gmin, przedsięwzięcia sportowo-kulturalne, tereny inwestycyjne i atrakcje turystyczne;

- głównym kanałem przekazu promocyjnego jest Internet, który wykorzystywany jest przez wszystkie gminy, a w mniejszym stopniu pozostałe media;

- stosowane przez władze gminy narzędzia promocji przyczyniają się do zwiększenia świadomości mieszkańców w zakresie atrakcyjności ich gminy oraz wzrostu zadowolenia, że są jej mieszkańcami.

\section{Podsumowanie}

Odpowiednio realizowane założenia marketingu terytorialnego są pomocnym narzędziem w realizacji celów zarządzania jednostką terytorialną. Odpowiednio zaplanowana strategia, uwzględniająca potencjalnych partnerów jest ważna. Pozwala na podjęcie decyzji adekwatnych do sytuacji, które wygenerują jak największe korzyści dla gminy. Można wskazać na wysoką efektywność zarządzania marketingowego $\mathrm{w}$ kreowaniu rozwoju gminy. To właśnie dzięki niemu dana gmina potrafi odpowiednio dostosować się do nieustannych zmian, które zachodzą $\mathrm{w}$ jej otoczeniu, a także odnosić sukcesy i rozwijać się w długim czasie, głównie w oparciu o własne produkty, usługi czy też zasoby. Warto w tym miejscu dodać, iż najistotniejszym członem owej koncepcji są urzędnicy gminy, którzy powinni reprezentować postawy pro marketingowe $\mathrm{i}$ właściwie z nich korzystać.

Uwzględniając wyniki badań własnych, przeprowadzonych na terenie gmin województwa łódzkiego, należy wskazać, że założenia marketingu terytorialnego są stosowane coraz częściej i odgrywają istotną rolę w działaniach władz samo- rządowych. Podstawowym celem realizowanych działań jest różnorodny rozwój gmin dla osiągnięcia jak największych korzyści. Odpowiednio wykorzystane założenia marketingu terytorialnego pozwalają poprawić sytuację gminy w wielu płaszczyznach. Aspekt ekonomiczny tej formy marketingu jest niewątpliwie jednym z najbardziej istotnych elementów. W tym kontekście ważna jest również, prowadzona $\mathrm{w}$ zakresie zarządzania marketingowego, odpowiednia i przemyślana promocja regionu. Może ona spowodować wzrost atrakcyjności danego regionu nie tylko dla mieszkańców, ale również dla podmiotów zewnętrznych, które rozpoczną prowadzenie inwestycji w gminie. Dzięki takim działaniom gminy mogą sprostać aktualnym wyzwaniom związanym z lokalnym rozwojem.

$\mathrm{Na}$ podstawie niniejszych rozważań można wysnuć wniosek, że w celu zwiększenia atrakcyjności danego regionu, władze gminy coraz częściej sięgają po regularne i długookresowe działania marketingowe. Zarządzanie marketingowe jest $\mathrm{w}$ tej kwestii istotnym narzędziem, aby móc osiągnąć ważne cele danej gminy. Uzyskane rezultaty pozwalają stwierdzić, że władze badanych jednostek terytorialnych zdają sobie sprawę z korzyści marketingu terytorialnego dla rozwoju gmin. Ponadto, w badanych gminach obserwuje się działania skoncentrowane na osiąganie zamierzonych celów, których zadaniem jest rozwój gminy i jej rozpoznawalność $\mathrm{w}$ regionie. W stosowaniu marketingu terytorialnego istotne są kompetencje i umiejętności kadry zarządzającej oraz pracowników gmin. Pozwalają im one na stosowanie i umiejętne wykorzystywanie narzędzi marketingu w zarządzaniu, ukierunkowanym na osiąganie zamierzonych celów w rozwoju gminy. 


\section{Bibliografia:}

1. Bąk M. [2006], Promocja gminy, miasta i regionu $w$ kontekście integracji europejskiej. Techniki przygotowania materiatów promocyjnych i ofert inwestycyjnych. Zasady obstugi inwestorów, TWIGGER, Warszawa.

2. Castenow D. [1996], Nowy marketing w praktyce, Warszawa, PWE.

3. Chrząścik M. [2012], Znaczenie strategii promocji w zarządzaniu wizerunkiem jednostki terytorialnej, Zeszyty Naukowe Uniwersytetu Przyrodniczo-Humanistycznego w Siedlcach, Seria: Administracja i Zarządzanie, nr 94.

4. Domański R. [2006], Gospodarka przestrzenna. Podstawy teoretyczne, Warszawa, Wydawnictwo Naukowe PWN.

5. Florek M. [2007], Promocja $w$ marketingu terytorialnym, Podstawy marketingu terytorialnego, Wydawnictwo Akademii Ekonomicznej w Poznaniu.

6. Gregor B., Gotwald-Feja B. [2016], Komunikacja marketingowa w JST na przyktadzie powiatów, w: Wspótczesne koncepcje zarządzania publicznego. Wyzwania modernizacyjne sektora publicznego, M. Ćwiklicki, M. Jabłoński, S. Mazur (red.), Kraków, Wyd. Fundacja Gospodarki i Administracji Publicznej.

7. Kłosiewicz-Górecka U., Słomińska B. [2001], Samorząd terytorialny a rozwój nowoczesnego handlu, Warszawa, Difin.

8. Kowalczyk L. [2004], Zarządzanie miastem, w: Ekonomika i zarządzanie miastem, R. Brol (red.), Wrocław, Wyd. AE im. Oskara Langego.

9. Kuźniar W. [2013], Organizacyjne aspekty rozwoju marketingu terytorialnego w gminach turystycznych, „Finanse i Marketing”, nr 10(59), Polityki Europejskie.

10. Mikołajczyk A. [2010/2011], Budowa marki miasta, „Magazyn THINKTANK”.

11. Noworól A. [2007], Planowanie rozwoju terytorialnego w skali regionalnej i lokalnej, Kraków, Wydawnictwo Uniwersytetu Jagiellońskiego.

12. Noworól A. [2013], Zarządzanie rozwojem w kontekście nowej polityki regionalnej, Zeszyty Naukowe Uniwersytetu Ekonomicznego w Katowicach, nr 169, s. 163-164.

13. Parysek J. [2010], Rola planowania w rozwoju spoteczno-gospodarczym i przestrzennym miast polskich po 1989 roku, w: Studia miejskie. Koncepcje i instrumenty zarządzania procesami rozwoju i rewitalizacji miast, J. Słodczyk, E. Szafranek (red.), Opole, Wyd. Uniwersytetu Opolskiego.

14. Sekuła A. [2002], Marketingowe zarządzanie regionem, w: Marketing w rozwoju regionu. Wybrane zagadnienia, J. Karwowski (red.), Uniwersytet Szczeciński, Szczecin.

15. Strużycki M., Nowacki R. [2002], Reklama w przedsiębiorstwie, Warszawa, Difin.

16. Urban S. [2003], Strategia rozwoju gminy, „Współczesne Zarządzanie. Kwartalnik Środowisk Naukowych i Liderów Biznesu”, nr 2.

17. Wojciechowski E. [2003], Zarządzanie w samorządzie terytorialnym, Warszawa, Difin.

18. Zieman-Miszewska E. [2005], Wykorzystanie marketingu $w$ budowaniu przewagi konkurencyjnej regionów, w: Międzynarodowe uwarunkowania konkurencyjności regionu, W. Kosiedowski (red.), Toruń, UMK-WTN.

19. Ziółkowski M. [2015], Strategiczne zarządzanie rozwojem gminy, Ruch Prawniczy, Ekonomiczny i Socjologiczny, Rok LXXVII, zeszyt 1.

Mgr ekonomii Krzysztof Jędrzejewski, doktorant, Katedra Marketingu, Uniwersytet Łódzki. 